\title{
One Fungus, One Name: Defining the Genus Fusarium in a Scientifically Robust Way That Preserves Longstanding Use
}

\author{
David M. Geiser, Takayuki Aoki, Charles W. Bacon, Scott E. Baker, Madan K. Bhattacharyya, Mary E. Brandt, \\ Daren W. Brown, Lester W. Burgess, Sofia Chulze, Jeffrey J. Coleman, James C. Correll, Sarah F. Covert, \\ Pedro W. Crous, Christina A. Cuomo, G. Sybren De Hoog, Antonio Di Pietro, Wade H. Elmer, Lynn Epstein, \\ Rasmus J. N. Frandsen, Stanley Freeman, Tatiana Gagkaeva, Anthony E. Glenn, Thomas R. Gordon, \\ Nancy F. Gregory, Kim E. Hammond-Kosack, Linda E. Hanson, María del Mar Jímenez-Gasco, Seogchan Kang, \\ H. Corby Kistler, Gretchen A. Kuldau, John F. Leslie, Antonio Logrieco, Guozhong Lu, Erik Lysøe, Li-Jun Ma, \\ Susan P. McCormick, Quirico Migheli, Antonio Moretti, Françoise Munaut, Kerry O’Donnell, Ludwig Pfenning, \\ Randy C. Ploetz, Robert H. Proctor, Stephen A. Rehner, Vincent A. R. G. Robert, Alejandro P. Rooney, \\ Baharuddin bin Salleh, Maria Mercedes Scandiani, Jonathan Scauflaire, Dylan P. G. Short, Emma Steenkamp, \\ Haruhisa Suga, Brett A. Summerell, Deanna A. Sutton, Ulf Thrane, Francis Trail, Anne Van Diepeningen, \\ Hans D. VanEtten, Altus Viljoen, Cees Waalwijk, Todd J. Ward, Michael J. Wingfield, Jin-Rong Xu, \\ Xiao-Bing Yang, Tapani Yli-Mattila, and Ning Zhang
}

First, twenty-seventh, twenty-eighth, and thirtieth authors: Department of Plant Pathology, Pennsylvania State University, University Park 16802; second author: National Institute of Agrobiological Sciences, Genetic Diversity Department, 2-1-2 Kannondai, Tsukuba, Ibaraki 305-8602, Japan; third and twenty-second authors: Toxicology and Mycotoxin Research, USDA-ARS-SAA, Athens, GA 30605-2720; fourth author: Pacific Northwest National Laboratory, Richland, Washington 99352; fifth and sixty-fourth authors: Department of Plant Pathology and Microbiology, Iowa State University, Ames, IA 50011; sixth author: Centers for Disease Control and Prevention, Atlanta, GA 30333; seventh, thirty-sixth, fortieth, forty-third, forty-sixth, and sixty-first authors: NCAUR-ARS-USDA, Peoria, IL 61604; eighth author: Faculty of Agriculture, University of Sydney, Sydney, New South Wales, Australia; ninth author: Department of Microbiology and Immunology, Universidad Nacional de Rio Cuarto, Rio Cuarto, Córdoba, Argentina; tenth author: Department of Medicine, Massachusetts General Hospital, Boston 02114; eleventh author: Department of Plant Pathology, University of Arkansas, Fayetteville, AR 72701; twelfth author: Warnell School of Forestry and Natural Resources, University of Georgia, Athens, GA 30602; thirteenth, fifteenth, forty-fifth and fifty-seventh authors: CBS-KNAW Fungal Biodiversity Center, Utrecht, Netherlands; fourteenth author: Broad Institute of MIT and Harvard, Cambridge, MA 02142; sixteenth author: Departamento de Genética, Universidad de Córdoba, Córdoba, Spain; seventeenth author: Department of Plant Pathology, Connecticut Agricultural Experiment Station, New Haven, CT 06504; eighteenth and twenty-third authors: Department of Plant Pathology, University of California, Davis 95616; nineteenth and fifty-fifth authors: Department of Systems Biology, Technical University of Denmark, Lyngby, Denmark; twentieth author: Department of Plant Pathology and Weed Research, Agricultural Research Organization (ARO), The Volcani Center, Bet Dagan, Israel; twenty-first author: Laboratory of Mycology and Phytopathology, All-Russian Institute of Plant Protection, St. Petersburg-Pushkin, Russia 196608; twenty-fourth author: Department of Plant \& Soil Sciences, University of Delaware, Newark, DE 19716; twenty-fifth author: Centre for Sustainable Pest and Disease Management, Rothamsted Research, Harpenden AL5 2JQ, UK; twenty-sixth author: ARS-USDA Sugarbeet and Bean Research Unit, East Lansing, MI 48824; twenty-ninth author: ARS-

Corresponding author: D. Geiser; E-mail address: dgeiser@psu.edu

http://dx.doi.org/10.1094/PHYTO-07-12-0150-LE

(C) 2013 The American Phytopathological Society
USDA Cereal Disease Laboratory, St. Paul, MN 55108; thirty-first author: Department of Plant Pathology, Kansas State University, Manhattan, KS 66506; thirty-second and thirty-eighth authors: CNR (Research National Council), ISPA Institute of Sciences of Food Production, Bari, Italy; thirty-third author: Research Center for Bio-Resources and Environment, Dalian Nationalities University, Liaoning, P.R. China; thirty-fourth author: Department of Plant Health and Plant Protection, Bioforsk-Norwegian Institute of Agricultural and Environmental Research,1432 Ås, Norway; thirtyfifth author: Department of Plant, Soil and Insect Sciences, University of Massachusetts, Amherst, MA 01003; thirty-seventh author: Dipartimento di Protezione delle Piante, Universita degli Studi di Sassari, Italy; thirty-ninth and forty-ninth authors: Universite Catholique de Louvain, Earth and Life Institute, Louvain-laNeuve, Belgium; forty-first author: Departamento de Fitopatologia, Universidade Federal de Lavras, MG, Brazil; forty-second author: Department of Plant Pathology, Tropical Research and Education Center, University of Florida, Homestead, FL 33031; forty-fourth author: Systematic Mycology and Microbiology Laboratory, United States Department of Agriculture, Agricultural Research Service, Beltsville, MD 20705; forty-seventh author: School of Biological Science, Science University of Malaysia, Penang, Malaysia; fortyeighth author: Laboratorio Agrícola Río Paraná, San Pedro, Buenos Aires, Argentina; fiftieth author: Department of Plant Pathology, University of California, Davis, c/o U.S. Agricultural Research Station, Salinas, CA 93905; fifty-first and sixty-second authors: Forestry and Agricultural Biotechnology Institute (FABI), Department of Microbiology and Plant Pathology, University of Pretoria, South Africa; fifty-second author: Life Science Research Center, Gifu University, Gifu, Japan; fifty-third author: The Royal Botanic Garden Sydney, Sydney, NSW 2000, Australia; fifty-fourth author: Department of Pathology, University of Texas Health Science Center, San Antonio, TX 78229; fifty-sixth author: Department of Plant Biology, Michigan State University, East Lansing 488241312; fifty-eighth author: Division of Plant Pathology and Microbiology, University of Arizona, Tucson 85721; fifty-ninth author: Department of Plant Pathology, University of Stellenbosch, Private Bag X1, Matieland 7602, South Africa; sixtieth author: Plant Research International, Wageningen University and Research, P.O. Box 16, 6700 Wageningen, The Netherlands; sixty-third author: Department of Plant Pathology, Purdue University, West Lafayette, IN 47907; sixty-fifth author: Laboratory of Plant Physiology and Molecular Biology, Department of Biology, University of Turku, FIN-20014 Turku, Finland; and sixty-sixth author: Department of Plant Biology \& Pathology, Rutgers University, New Brunswick, NJ 08901.

Accepted for publication 12 November 2012. 


\section{ABSTRACT}

Geiser, D. M., Aoki, T., Bacon, C. W., Baker, S. E., Bhattacharyya, M. K., Brandt, M. E., Brown, D. W., Burgess, L. W., Chulze, S., Coleman, J. J., Correll, J. C., Covert, S. F., Crous, P. W., Cuomo, C. A., De Hoog, G. S., Di Pietro, A., Elmer, W. H., Epstein, L., Frandsen, R. J. N., Freeman, S., Gagkaeva, T., Glenn, A. E., Gordon, T. R., Gregory, N. F., HammondKosack, K. E., Hanson, L. E., del Mar Jímenez-Gasco, M., Kang, S., Kistler, H. C., Kuldau, G. A., Leslie, J. F., Logrieco, A., Lu, G., Lysøe, E., Ma, L.-J., McCormick, S. P., Migheli, Q., Moretti, A., Munaut, F., O’Donnell, K., Pfenning, L., Ploetz, R. C., Proctor, R. H., Rehner, S. A., Robert, V. A. R. G., Rooney, A. P., bin Salleh, B., Scandiani, M. M., Scauflaire, J., Short, D. P. G., Steenkamp, E., Suga, H., Summerell, B. A., Sutton, D. A., Thrane, U., Trail, F., Van Diepeningen, A., VanEtten, H. D., Viljoen, A., Waalwijk, C., Ward, T. J., Wingfield, M. J., Xu, J.-R., Yang, X.-B., Yli-Mattila, T., and Zhang, N. 2013. One fungus, one name: Defining the genus Fusarium in a scientifically robust way that preserves longstanding use. Phytopathology 103:400-408.
In this letter, we advocate recognizing the genus Fusarium as the sole name for a group that includes virtually all Fusarium species of importance in plant pathology, mycotoxicology, medicine, and basic research. This phylogenetically guided circumscription will free scientists from any obligation to use other genus names, including teleomorphs, for species nested within this clade, and preserve the application of the name Fusarium in the way it has been used for almost a century. Due to recent changes in the International Code of Nomenclature for algae, fungi, and plants, this is an urgent matter that requires community attention. The alternative is to break the longstanding concept of Fusarium into nine or more genera, and remove important taxa such as those in the $F$. solani species complex from the genus, a move we believe is unnecessary. Here we present taxonomic and nomenclatural proposals that will preserve established research connections and facilitate communication within and between research communities, and at the same time support strong scientific principles and good taxonomic practice.
The importance of the name Fusarium. When we say, "I work on Fusarium," we mean we work on a fungus that causes plant and animal diseases, produces mycotoxins, has six species with complete genome sequences in advanced stages of annotation and many more in progress, has revealed fascinating modes of genetic change with broad evolutionary implications (23) and can be consumed as a processed food (i.e., Quorn). In a recent survey among the international community of plant pathologists, two Fusarium species, $F$. graminearum and $F$. oxysporum were ranked fourth and fifth, respectively, on a list of top 10 fungal plant pathogens based on scientific/economic importance (12). When we conduct research on Fusarium, we can feel reasonably confident that its prospects will be aided by the recognized significance of the group. When we publish a paper with "Fusarium" in the title, the genus' h-index (19) of 66 since 2002 (Table 1) should give us confidence that it has a huge audience. And perhaps most importantly, there is a large and active research community that identifies strongly with the name and interacts through a Fusarium Subcommittee of the International Society of Plant Pathology, a Fusigroup that focuses on genomics and meets in conjunction with the U.S. and European Fungal Genetics Conferences, an International Fusarium Workshop that convenes every 5 years, and annual Fusarium Laboratory Workshops that have been held every year since 2001. Special journal issues and symposia on Fusarium are commonplace in the fields of plant pathology, mycology, and mycotoxicology. In addition to a community of applied and basic researchers focused on a group of organisms represented by the name Fusarium, the name is also the primary portal that brings outside researchers and citizens with little or no experience in systematics or mycology, including plant breeders, producers of food and other products, genomicists, farmers, and physicians, into contact with the Fusarium community. Thus, the name is an important facilitator of communication, both among members of the Fusarium community and in making connections to its stakeholders. As we go about conducting research, writing grant proposals and papers, and attending workshops focused on Fusarium, most of us give little if any thought to what Fusarium is and what it is not. We are now presented with an urgent need to give this matter some serious thought.

This year witnesses an important and transformational change for Fusarium systematics, yet the Fusarium community may not realize its far-reaching impact. Fungi that produce asexual and sexual stages ("pleomorphic fungi") have been allowed under a special provision of the former International Code of Botanical Nomenclature (ICBN, Article 59) to have separate names referring to the sexual ("teleomorph") and asexual stages ("anamorph"); when referring to the whole fungus ("holomorph"), the teleomorph name has taken precedence, at least until now. At the 2011 meeting of the Nomenclature Session of the Botanical Congress in Melbourne, it was decided that the former Article 59 will no longer apply as of 1 January 2013 (18). Under this provision ["One Fungus One Name or "1F1N"; (44)], all names, whether they are typified by an anamorph or a teleomorph, will be on equal footing in terms of priority, so the opportunity exists to conserve anamorph names such as Fusarium in a way that the scientific community sees fit.

TABLE 1. Reference and internet search results for 15 agriculturally and medically important fungal/oomycete names; names associated with Fusarium are in bold

\begin{tabular}{|c|c|c|c|}
\hline Taxon $^{\mathrm{a}}$ & References $^{b}$ & h-index ${ }^{c}$ & Google hits \\
\hline Saccharomyces & 9,917 & 108 & $7,620,000$ \\
\hline Candida & 9,016 & 100 & $39,900,000$ \\
\hline Aspergillus & 7,822 & 81 & $6,440,000$ \\
\hline Fusarium & 5,397 & 66 & $3,810,000$ \\
\hline Cryptococcus & 1,665 & 59 & 395,000 \\
\hline Neurospora & 789 & 51 & 317,000 \\
\hline Phytophthora & 2,656 & 48 & $1,920,000$ \\
\hline Trichoderma & 1,738 & 45 & $1,790,000$ \\
\hline Penicillium & 2,066 & 35 & $2,470,000$ \\
\hline Magnaporthe & 619 & 37 & 671,000 \\
\hline Ustilago & 368 & 34 & 171,000 \\
\hline Colletotrichum & 1,032 & 31 & 673,000 \\
\hline Gibberella & 277 & 30 & 314,000 \\
\hline Verticillium & 749 & 29 & 282,000 \\
\hline Mycosphaerella & 401 & 28 & 513,000 \\
\hline Alternaria & 965 & 28 & $1,230,000$ \\
\hline Nectria & 51 & 11 & 388,000 \\
\hline Neocosmospora & 8 & 2 & 62,200 \\
\hline Haematonectria & 2 & 1 & 14,900 \\
\hline Cyanonectria & 2 & 2 & $\mathbf{8 , 7 5 0}$ \\
\hline Geejayessia & 1 & 1 & 1,050 \\
\hline Albonectria & 1 & 1 & 7,260 \\
\hline Fusarium solani & 299 & 21 & 433,000 \\
\hline Nectria haematococca & 27 & 10 & 207,000 \\
\hline Fusarium graminearum & 568 & 37 & 447,000 \\
\hline Gibberella zeae & 152 & 24 & 132,000 \\
\hline Fusarium verticillioides & 285 & 24 & 133,000 \\
\hline Gibberella moniliformis & 11 & 6 & 51,700 \\
\hline
\end{tabular}

a Taxon names in bold are associated with the terminal Fusarium clade.

${ }^{b}$ References published from 2002 to present were retrieved from ISI Web of Knowledge on 14 May 2012 using the taxon name as a query under "Title."

${ }^{c} \mathrm{~h}$-index is the number of references with at least that number or more citations. For example, of the 5,397 references with Fusarium in the title, 66 have been cited at least 66 times.

${ }^{\mathrm{d}}$ Hits retrieved using the taxon name as a query in the Google search engine, from Penn State campus on 14 May 2012. 


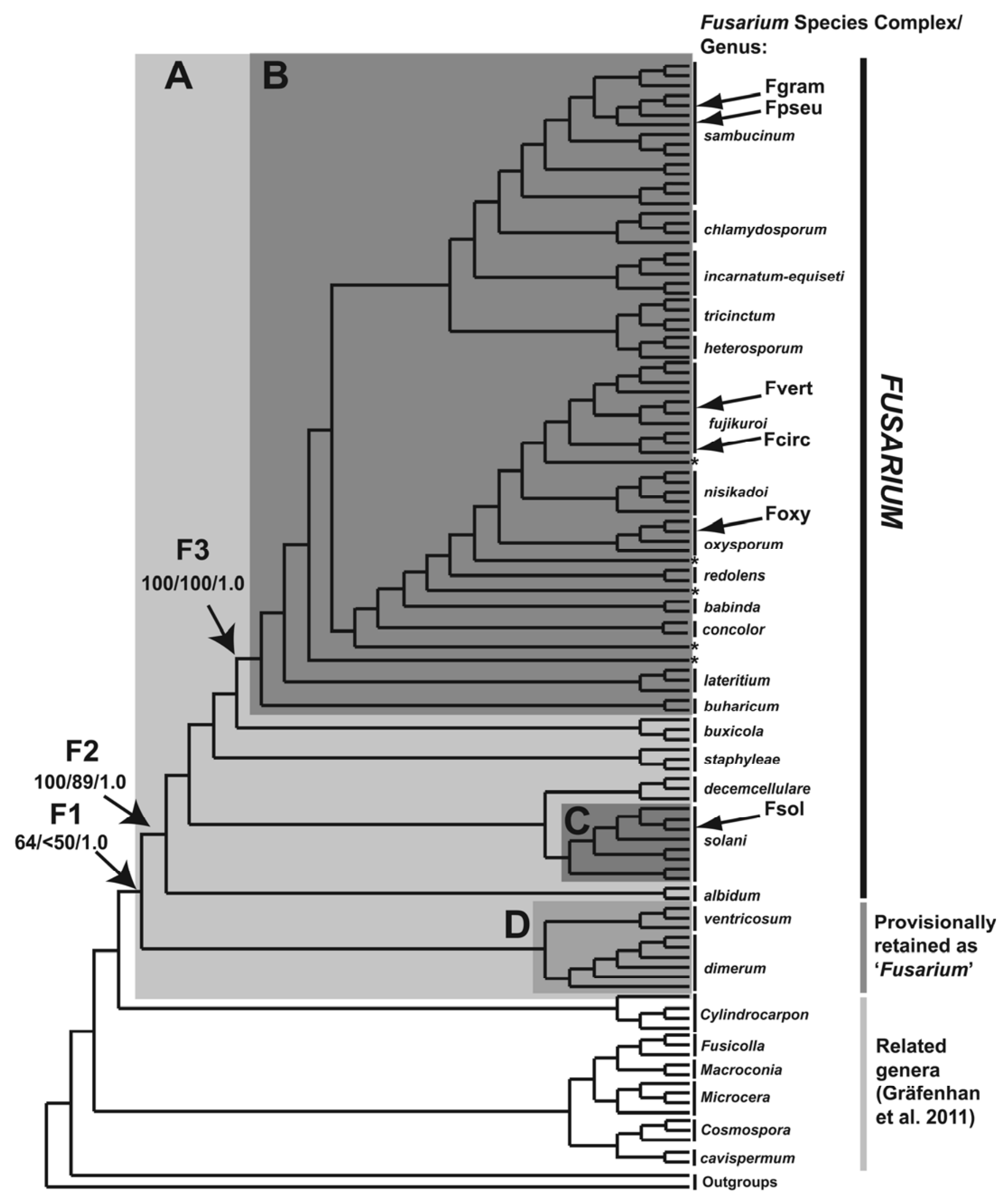

Fig. 1. Cladogram presentation of the RPB1/RPB2 phylogenetic tree presented in O'Donnell et al. (28). The cladogram is based on one of four most parsimonious trees; see O'Donnell et al. (28) for methodological details. Branch lengths are arbitrary. Values associated with labeled nodes indicate the maximum likelihood bootstrap (ML-BS), maximum parsimony bootstrap (MP-BS), and Bayesian posterior probability (B-PP) values. Major clades/species complexes are labeled on the right, with monotypic taxa marked by an asterisk. Arrows on the right indicate species for which complete genome sequences are released and in an advanced state of annotation: Fgram $=$ F. graminearum, FPseu $=$ F. pseudograminearum, Fvert $=$ F. verticillioides, Fcirc $=$ F. circinatum, Foxy $=F$. oxysporum, and Fsol $=$ F. solani species complex phylogenetic species $11(8,11,13,23,45)$. A, Our proposed limits for the use of Fusarium as a unitary name, delimited by Node F1. B, Limitation of Fusarium to Gibberella Clade, delimited by Node F3. C, The F. solani species complex. D, The F. ventricosum and $F$. dimerum species complexes, subjected to provisional status as Fusarium, awaiting strongly supported phylogenetic inferences that either support or reject their inclusion. 
This means the second-class nomenclatural status of Fusarium as an anamorph genus will end, allowing the exclusive use of the name Fusarium without additional teleomorph names. Fusarium researchers have been moving in this direction in recent years, describing sexual stages without a corresponding teleomorph name $(9,36)$. Historically, taxonomic treatments of Fusarium have stressed the anamorph $(2,3,14,15,20,21,24,26,32,40-42,46)$, since teleomorphs are unknown for a large majority of the species, and anamorphs are almost always what plant pathologists and other applied biologists observe in culture. An alternative option would be to let Fusarium be subsumed entirely under existing teleomorph names, but virtually everyone would agree that conserving its further use is the most desirable outcome. The question is: to what species and clades should the name apply? The way we resolve this question will significantly impact how we study and publish Fusarium for the foreseeable future.

Our Proposal. Here we argue that the name Fusarium should be applied exclusively to all members of a monophyletic group that best fits the longstanding concept of the genus, protected against all competing teleomorph concepts within that group. Recent phylogenetic hypotheses offer two competing monophyletic groups that are potential targets for exclusive use of the name Fusarium, presented as nodes F1 and F2 in Figure 1. Both groups include every Fusarium species of major research interest, with $\mathrm{F} 2$ excluding the $F$. dimerum and $F$. ventricosum complexes. The clade associated with node F1, recently referred to as "the terminal Fusarium clade," was resolved as monophyletic $(16,37)$, but with weak statistical support. In a more comprehensive analysis, F1 received improved support but only in Bayesian analysis, and F2 was strongly supported using three analytical approaches (28). Here we assign Fusarium to node F1, but retain the $F$. dimerum and $F$. ventricosum complexes only provisionally as Fusarium, recognizing the need for further study.

Didn't the taxonomists tell us to use teleomorph genus names forty years ago? The research communities invested in Fusarium now have an opportunity to adopt a simple and rational system where every Fusarium species is referred to solely by the name of this well-known anamorph. Scientists likely recall being told to adopt the use of teleomorph names, so a proposal to go back to using Fusarium will be met with skepticism. Researchers working on members of the $F$. solani species complex faithfully adopted the teleomorph name Nectria haematococca for their organisms of choice in the 1970s (43), only to learn a couple of decades later that the name Nectria had been misapplied to this group (34), with no satisfactory teleomorph name replacing it (27). Quite reasonably, some of these workers have chosen to keep using the name Nectria in the face of the taxonomic instability, particularly applied to $N$. haematococca mating populations (8). Our intent here is to establish a scientifically robust yet practical and stable usage that will optimally serve all Fusarium research in the long run. While $N$. haematococca remains in use, it will become more and more difficult to communicate in the literature and elsewhere without using a standardized nomenclature.

Biological databases such as MycoBank (10) and GenBank will likely have the greatest influence on usage. MycoBank was established as the central depository of fungal names and naturally, GenBank looks to MycoBank and other mycological resources for guidance on fungal taxonomy. Still, the application of $\mathrm{Fu}$ sarium nomenclature in GenBank has been inconsistent. Currently, GenBank accessions from the $F$. solani species complex are deposited under four different genus names (i.e., Fusarium, Nectria, Neocosmospora, and its later synonym Haematonectria). In contrast, isolates of $F$. graminearum and $F$. verticillioides are consistently converted to their teleomorph names, Gibberella zeae and G. moniliformis. Of course, GenBank is not the source of this confusion; it only reflects the confused state of Dual Nomenclature associated with Fusarium. MycoBank and GenBank do not wish to impose a taxonomic view on users; they simply make an effort to communicate a framework as established by taxonomists. We expect that MycoBank and GenBank will adopt the circumscription of Fusarium put forward by the research community and accepted by the International Committee on Nomenclature, which means that the community must step forward to voice its needs, or face having the decision made for it. So what is to become of Fusarium species such as $N$. haematococca? We argue that it is far more desirable that they appear in GenBank as Fusarium species than as Haematonectria, Neocosmospora, or whatever other genus name might be proposed for them, as long as it is scientifically reasonable to do so.

Taxonomic changes based on scientifically robust principles are a good thing. Taxonomic name changes are often necessary and practical (33). We advocate employing a molecular phylogenetic approach to guide such changes so that taxonomy best aligns with evolutionary history and fully realizes its predictive potential. Such changes may be inconvenient, or rearrange longestablished taxonomic groups, but where they have a solid scientific foundation they facilitate good scientific practice and guide biological discovery. With the move away from Dual Nomenclature, certainly some radical changes will be necessary in many fungal groups, but these are ultimately in the best interests of scientific progress. Many such practical changes have already occurred in Fusarium. In addition to those cited in Rossman and Palm-Hernandez (33), F. nivale was moved from Fusarium to Microdochium based on morphological data (35); because the two genera reside in different subclasses of Ascomycota (Fusarium in Hypocreomycetidae, Microdochium in Xylariomycetidae), science was poorly served by the previous misplacement of $M$. nivale in Fusarium. Using phylogenetics as a guide, Gräfenhan et al. (16) segregated a large number of phylogenetically disjunct species from Fusarium into existing, revised, and new genera in the Nectriaceae. Most of these changes, which removed obscure species of little or no known practical importance, represent significant and practical advances in Fusarium systematics. However, as we will discuss later, we differ strongly with these authors regarding the eventual circumscription of Fusarium.

Criteria for circumscribing the genus Fusarium in a postArticle 59 world. We promote the following three standards in circumscribing the generic limits of Fusarium.

1. Monophyly: It should represent an evolutionarily exclusive lineage or monophyletic group that includes the type species (i.e., Fusarium sambucinum). Our circumscription of Fusarium is presented in Figure 1, and with more detail in Figure 1 of O'Donnell et al. (28).

2. Tradition: The monophyletic group should be chosen in the way that conforms best to longstanding taxonomic concepts of the genus as practiced by the broader plant pathological, mycotoxicological, and clinical microbiological research communities. The name should be applied to the most inclusive clade where the name Fusarium has been most commonly and sensibly used. In other words, the best solution is that of primum non nocere: first do no harm, and avoid unnecessary changes to the practical concept.

3. Fusarium first: Teleomorph generic concepts are of extremely limited use within Fusarium. A large majority of cultures and diseased material that taxonomic end-users work with contain only asexual stages, and most Fusarium species, including many key groups such as the $F$. oxysporum complex, have no known sexual stage. Fortunately, with the long awaited changes in the Code, we are now in a position to abandon the use of teleomorph names altogether and simply refer to species by the Fusarium name. Furthermore, there is no compelling reason/data to support dividing Fusarium according to teleomorph, for the following two reasons: (i) there is a longstanding tradition of 
Fusarium encompassing multiple teleomorphs $(5,39)$, and (ii) teleomorph evolution, as guided by existing morphological concepts, does not show clear evolutionary patterns. For example, Neocosmospora and Haematonectria teleomorphs are produced by closely related species within the F. solani species complex, rendering the concept of Haematonectria nonmonophyletic (27) and Fusarium species with Albonectria states are polyphyletic (16). In addition, the genus Fusarium traces back to Link in 1809 (22), and thus has nomenclatural priority over all associated teleomorph genera. Not surprisingly, Google searches retrieved over five times more records for Fusarium than all associated teleomorph names combined (Table 1), so a practical solution also puts Fusarium first.

\section{PROPOSAL}

Unitary use of the name Fusarium should be applied to all descendants of the node first defined as the terminal Fusarium clade by Gräfenhan et al. (16) and refined by O'Donnell et al. (28).

Phylogenetic definition. Here we apply the rules of PhyloCode (6) to provide a phylogenetic definition of Fusarium, which can be amended easily as new data and phylogenetic inferences are obtained.

Fusarium E. Fries 1821: Systema Mycologicum 1. XLI (Introductio) [D.M. Geiser \& K. O'Donnell, circumscribed herein], converted clade name.

Definition. The least inclusive clade containing Fusarium ventricosum Appel \& Wollenw. 1913, F. dimerum Penz. 1882, F. nematophilum Nirenberg \& G. Hagedorn 2010, F. decemcellulare Brick 1908, F. buxicola Sacc. 1883, F. staphyleae Samuels \& Rogerson 1984, F. solani (Mart.) Sacc. 1881, and F. sambucinum Fuckel 1870. This is a node-based definition in which all of the specifiers are extant and therefore designates a crown clade. Abbreviated definition: Fusarium ventricosum Appel \& Wollenw. 1913, F. dimerum Penz. 1882, F. nematophilum Nirenberg \& G. Hagedorn 2010, F. decemcellulare Brick 1908, F. buxicola Sacc. 1883, F. staphyleae Samuels \& Rogerson 1984, F. solani (Mart.) Sacc. 1881, \& F. sambucinum Fuckel 1870.

Etymology. Derived from the Latin fusus (spindle), describing the typical septate conidia produced by most species.

Reference phylogeny. Based on largest and second largest RNA polymerase II B subunit ( $R P B 1$ and $R P B 2)$ gene sequences, labeled as Node F1 in Figure 1 of O'Donnell et al. (28).

Composition. Encompasses at least 20 genealogically exclusive lineages: F. sambucinum, F. chlamydosporum, F. incarnatumequiseti, F. tricinctum, F. heterosporum, F. fujikuroi, F. nisikadoi, $F$. oxysporum, $F$. redolens, $F$. babinda, F. concolor, F. lateritium, $F$. buharicum, $F$. buxicola, $F$. staphyleae, F. solani, F. decemcellulare, $F$. albidum, $F$. dimerum, and $F$. ventricosum species complexes or clades. See Node F1 in Figure 1 of O'Donnell et al. (28).

Diagnostic apomorphies. No true morphological synapomorphies are known for this clade. Asexual spores may include any or all of the following: (i) curved, transversely septate conidia ("macroconidia") produced from sporodochia or pionnotes, (ii) generally smaller conidia of various shapes and septation ("microconidia" and/or "mesoconidia") produced from unbranched or branched mycelial conidiophores, producing conidiogenous cells with one (monophialidic) or more (polyphialidic) openings, and (iii) thick-walled, generally globose thallospores (chlamydospores) produced in or on hyphae or conidia, singly or in chains or bunches. Sexual spores, when observed, produced in flaskshaped fruiting bodies (perithecia) that are usually in shades of red, orange, blue or purple, with little or no stromatal tissue. Asci produced from distinct hymenia, single-walled (unitunicate) containing eight ascospores, which usually possess one or more septa, but can be aseptate.
Comments. Fusarium, first described by Link (1809: Mag. Ges. Naturf. Freunde, Berlin 3:10), was sanctioned under Fries 1821. Anamorphs within this clade have consistently been described as Fusarium, with occasional isolates or species classified in other genera including Acremonium, Cylindrocarpon, Pycnofusarium, Trichofusarium, and Cephalosporium, particularly when the macroconidial morph is not observed. The inclusion of the $F$. dimerum and $F$. ventricosum species complexes is provisional, due to the weak bootstrap support for the node that includes them in maximum likelihood and maximum parsimony analyses $(16,28,37)$. Bayesian analysis offers strong support (posterior probability $[\mathrm{PP}]=100 \%$ ) for the clade that includes these taxa (Node F1), and the only existing evidence supports their inclusion. Additional phylogenetic and taxonomic work will determine the nomenclatural fate of species in these clades.

Nomenclature. The above phylogenetic delimitation of $\mathrm{Fu}$ sarium will require nomenclatural changes to accommodate it in practice. Several generic names, mostly referring to sexual stages, are typified within the terminal Fusarium clade, including the name Gibberella. In fact, the names Fusarium and Gibberella are typified in the same member of the terminal Fusarium clade, F. sambucinum Fuckel and its teleomorph G. pulicaris Fr. (Sacc.). To accommodate this phylogenetic delimitation in a logical way, the following combinations are required:

Fusarium albidum (Rossman) O'Donnell \& Geiser, comb. nov. MYCOBANK ID: MB 800574

三 Albonectria albida (Rossman) Guu \& Y.M. Ju, Bot. Stud. 48(2):189. 2007.

三Nectria albida Rossman, Mycol. Pap. 150:79. 1983.

Fusarium albosuccineum (Pat.) O'Donnell \& Geiser, comb. nov.

MYCOBANK ID: MB 800609

$\equiv$ Albonectria albosuccinea (Pat.) Rossman \& Samuels, in Rossman, Samuels, Rogerson \& Lowen, Stud. Mycol. 42:107. 1999.

$\equiv$ Calonectria albosuccinea Pat., Bull. Soc. Mycol. Fr. 8(2):132. 1892.

Fusarium verrucosum (Pat.) O'Donnell \& Geiser, comb. nov.

MYCOBANK ID: MB 800610

$\equiv$ Calonectria verrucosa Patouillard, Bull. Soc. mycol. Fr. 11(4):228. 1895.

$\equiv$ Albonectria verrucosa (Pat.) Rossman \& Samuels, in Rossman, Samuels, Rogerson \& Lowen, Stud. Mycol. 42:108. 1999.

= Nectria astromata Rossman, Mycotaxon 8(2):550. 1979.

Fusarium cicatricum (Berk.) O'Donnell \& Geiser, comb. nov.

MYCOBANK ID: MB 800611

$\equiv$ Geejayessia cicatricum (Berk.) Schroers, Stud. Mycol. 68(1):124. 2011.

三 Sphaeria sanguinea Bolton var. cicatricum Berk., Mag. Zool. Bot. 1:48. 1837.

Fusarium cyanostomum (Sacc. \& Flageolet) O’Donnell \& Geiser, comb. nov.

MYCOBANK ID: MB 800612

$\equiv$ Cyanonectria cyanostoma (Sacc. \& Flageolet) Samuels \& Chaverri, Mycol. Progr. 8(1):56. 2009.

三Nectria cyanostoma Sacc. \& Flageolet, Atti del Congr. bot. di Palermo:53. 1902.

Fusarium plagianthi (Dingley) O'Donnell \& Geiser, comb. nov.

MYCOBANK ID: MB 800613

$\equiv$ Nectria plagianthi Dingley, Trans. Roy. Soc. N.Z. 79(2):196. 1951.

Fusarium rusci (Sacc.) O'Donnell \& Geiser, comb. nov.

MYCOBANK ID: MB 800614

三 Trichofusarium rusci (Sacc.) Bubák, Bull. Herb. Boissier, 2 sér. 6:488. 1906.

$\equiv$ Fusarium roseum Link var. rusci Sacc., Michelia 2 (no. 7):294. 1881. 
= Pycnofusarium rusci D. Hawksw. \& Punith., Trans. Br. Mycol. Soc. 61(1):63. 1973.

Fusarium neocosmosporiellum O'Donnell \& Geiser, nom. nov. MYCOBANK ID: MB 800615

$\equiv$ Neocosmospora vasinfecta E.F. Sm., Bull. U.S. Department of Agriculture 17:45. 1899.

(non-Fusarium vasinfectum G.F. Atk. 1892).

\section{DISCUSSION}

Defining genera is an inherently subjective endeavor. Scientific principles govern good taxonomy, but taxonomists have choices regarding where to draw generic limits. In instances where monophyly (Criterion 1) and other scientific principles are satisfied, we have considerable latitude in Criteria 2 and 3 to accommodate practical concerns and longstanding use. Criterion 3 above, which gives greater weight to the name Fusarium, conflicts with approaches used to define genera of hypocrealean fungi established in Rossman et al. (34), which emphasizes teleomorph differences. Recent work by Schroers et al. (37) cites this approach as a guiding principle for revising the concept of Cyanonectria and describing the new genus Geejayessia, both of which are nested within the terminal Fusarium clade and consist entirely of species with typical Fusarium asexual stages. While in principle teleomorph differences may correlate well with genealogically exclusive groups and serve as a perfectly reasonable option for delimiting generic boundaries in many ascomycete groups, we argue that its application here is both impractical and scientifically unnecessary.

A monophyletic Fusarium. Multiple phylogenetic studies have resolved with varying support a monophyletic group that includes a large majority of species traditionally considered to be Fusarium that also includes virtually every species of agricultural, clinical, and research importance. This clade is referred to as the "terminal Fusarium clade" in Gräfenhan et al. (16); the type species of Fusarium, F. sambucinum, is nested within it. In that study this node received weak statistical support $[<95 \%$ Bayesian PP, $<75 \%$ maximum likelihood and parsimony bootstrap (ML and MP BS)], but the analysis was based only on partial sequences of the second largest RNA polymerase II B-subunit (RPB2) gene and ATP citrate lyase (acll), with $\sim 80 \%$ of the phylogenetic signal coming from $R P B 2$. In an analysis by Schroers et al. (37) based on the same gene regions, the terminal Fusarium clade received $76 \%$ MP BS support and 100\% PP. A neighboring clade (one that excludes two taxa labeled as 'Nectria' ventricosa) received "moderate" support (either $>75 \%$ ML or MP or $>95 \%$ PP) in their study. The terminal Fusarium clade received further support in our recent study utilizing sequences from both the largest and second largest ribosomal RNA polymerase II B-subunit genes ( $R P B 1$ and $R P B 2$ [28]). The two genes in this study provided relatively similar levels of phylogenetic signal, and were analyzed in a much more inclusive set of ingroup taxa $(n=93)$ than those of Gräfenhan et al. $(n=26)$ and Schroers et al. $(n=19)$. These genes resolved a node that is compatible to the terminal Fusarium clade (labeled "F1" in that study and in Figure 1), receiving $>95 \%$ PP, but ML and MP bootstrap support remained poor. The $R P B 1 / R P B 2$ study also resolved an alternative hypothesis to $\mathrm{F} 1$ for the circumscription of Fusarium (28). A clade nested within the terminal Fusarium clade, "F2", received much stronger statistical support (100\% ML BS, 87\% MP BS, and 100\% PP) and includes all of $\mathrm{F} 1$ except for the $F$. dimerum and $F$. ventricosum species complexes. Because of the inconsistent phylogenetic support for the inclusion of $F$. dimerum and $F$. ventricosum species complexes in the terminal Fusarium clade, their retention in Fusarium is given a provisional status in our proposal (Fig. 1D). While both of these groups have a long tradition of inclusion in Fusarium, and members of the F. dimerum species complex are occasional human pathogens and commonly encountered sapro- phytes (38), their removal from Fusarium will not have a great impact on common usage. Still, the only evidence available supports, less than convincingly, their retention in a monophyletic Fusarium, and at this time no compelling alternate nomenclatural options exist for them. Most importantly, both competing hypotheses for the circumscription of Fusarium strongly retain the economically important $F$. solani species complex in the genus.

Excluded taxa. A number of lineages basal to the terminal Fusarium clade that produce Fusarium-like anamorphs were recently moved to new, revised, or existing genera based on morphological and phylogenetic considerations (Microcera, Macroconia, Fusicolla, and Stylonectria [16]). Most of the Fusarium-like species in these basal lineages occur as saprophytes in soil, on trees and other fungi, and in aquatic habitats, but some are putative parasites of insects or endophytes. While these taxa traditionally have been included in treatments of Fusarium, they have not been reported to cause diseases of plants and humans and other vertebrates and none are known to produce mycotoxins, so they are largely ignored by applied biologists. Therefore, we support their removal from Fusarium with the caveat that it needs to be more fully assessed by additional data and analyses.

Comments on a somewhat conflicting viewpoint. Gräfenhan et al. (16) and Schroers et al. (37) also in effect argue for a phylogenetically based, unitary application of the name $\mathrm{Fu}$ sarium, but they focus on a single clade nested within the terminal Fusarium clade where a large majority of the known sexual stages fit the morphological concept of Gibberella (Node F3, Clade B in Fig. 1). This strongly supported "Gibberella clade" has been resolved consistently since the first molecular phylogenetic studies of Fusarium (17). Many economically important Fusarium species are nested within the Gibberella clade, including the type species of Fusarium (F. sambucinum), but it excludes many other agriculturally and medically important species, particularly those in the $F$. solani species complex, which are responsible for approximately two-thirds of all fusarial infections of humans and other animals (30).

The Gräfenhan et al. (16) and Schroers et al. (37) viewpoint is consistent with a tradition that emphasizes the teleomorph in recognizing generic boundaries. While this approach has been productive in delimiting genera in the Hypocreales (34), we argue that our "Fusarium First" approach is necessary because of the huge longstanding investment that has already been made in the name Fusarium, applied almost always to a group approximated by the terminal Fusarium clade. Generalizing beyond Fusarium to other genera of major importance, we offer a morph-neutral view regarding the precedence of teleomorph names. Once genealogically exclusive groups are identified, we advocate that a given genus name should be assigned to the most inclusive clade where the name has been most commonly and sensibly established, with no automatic preference given to genera typified as teleomorphs versus anamorphs. Unfortunately, many economically important genera are likely to be nonmonophyletic, necessitating radical changes.

The impact of limiting Fusarium to the Gibberella clade. The F. solani clade is represented in Figure 1C; Gräfenhan et al. (16) labeled taxa within this clade as "Haematonectria" or "Neocosmospora" but species in this group are mostly known as 'F. solani' or formae speciales of $F$. solani (e.g., F. solani f. sp. pisi). This group encompasses at least 60 phylogenetically diagnosable species, including many species of importance in agriculture, medicine and biological research, and as such, it has a long tradition of inclusion within the genus Fusarium (25). Members of this clade include a number of important pathogens of a variety of crops, including several species that cause sudden death syndrome of soybean (1). Members of the $F$. solani complex are the most common Fusarium species isolated from human infec- 
tions (30) and they accounted for the majority of the pathogens in the 2005-06 outbreaks of contact lens-associated corneal infections (7). Because of its status as a model system in plant pathology, and it is interesting metabolic capabilities, a member of ' $N$. haematococca MP VI' ("NhMPVI" or $F$. solani species complex phylogenetic species [11]) was targeted as one of the first Fusarium species for complete genome sequencing (8). Through comparisons of the NhMPVI genome with those of three species within in the Gibberella clade, some fascinating insights about the genomic nature of adaptation were revealed (8). Genomic characteristics of NhMPVI include an expanded genome due to the existence of small, conditionally dispensable chromosomes and large contiguous portions of chromosomes containing genes of unknown origin. Surprisingly, these are features it shares with $F$. oxysporum, a member of the Gibberella clade (23). In fact, $F$. solani (excluded from Fusarium if it is limited to the Gibberella clade) and $F$. oxysporum share a great deal of ecological and morphological similarities, and they are often presented together when individuals are trained to identify them morphologically. Based on the fact that some members of the $F$. solani species complex cause infections of plants and humans, a strong connection has been established among the medical and phytopathological communities that work on these Fusarium species and the broader Fusarium research communities. While the $F$. solani and $F$. oxysporum species complexes are clearly quite distinct phylogenetically, together they form part of a larger, strongly supported monophyletic group, so there is no compelling reason to overrule a century of established use and segregate the solani complex into a new genus.

The name $F$. solani in current usage has been applied to many of the 60 diagnosable phylogenetic species in the complex, reflecting the limitations of morphological species recognition within this species-rich complex. An alphanumerical system of nomenclature for phylogenetic species in the $F$. solani species complex provides that (29), but it is an incomplete substitute for an actual binomial. Providing such names must be a priority in parallel with the transition to $1 \mathrm{~N} 1 \mathrm{~F}$ usage.

A number of other fungi with a clear connection to Fusarium would be removed if the name were restricted to the Gibberella clade, including $F$. buxicola and $F$. decemcellulare, not to mention the $F$. dimerum species complex. While most of these fungi are of unknown economic importance, a large majority of them produce a classic Fusarium anamorph $(37,38)$. We argue that recognizing the limits of the genus as the node corresponding to F1 in Figure 1 , or a nearby node revealed through more thorough phylogenetic analyses, will avoid the unnecessary splitting of this cohesive group. At the same time, we strongly concur with the goal of Gräfenhan et al. (16), to "provide a functional single-name system that respects the principles of the ICBN and refrain from attempting to perpetuate a dual nomenclatural system where it is unlikely to be used by most scientists working on the practical aspects of these fungi," and offer this alternative proposal in the same spirit.

Summary and further considerations. In accordance with changes in the International Code of Nomenclature for algae, fungi, and plants, we propose the sole use of the name Fusarium to the clade representing the terminal Fusarium clade $(16,28,37)$ (Node F1 in Fig. 1), with the $F$. dimerum and $F$. ventricosum species complexes retained in a provisional status, effective 1 January 2013. An obvious advantage is that our proposal will circumvent a need to use at least eight generic names in that lineage. We also voice our strong opposition to any proposal to name any other subclade at the rank of genus within this clade, including the phylogenetically and morphologically diverse lineages within the Gibberella clade. Assuming that the proposal for unitary use of the name Fusarium is accepted and applied, further research is needed to refine the generic boundary, and most importantly, to accurately assign species names within the genus. Fusarium remains littered with names in use that are typified ambiguously, or lack types entirely; the work of Gräfenhan et al. (16) is an excellent start in this endeavor. A first effort to solve this problem involves making a list of names in use within the genus that can then be scrutinized one by one. In addition to existing names, scores of unnamed phylogenetic species are being recognized, and we need a robust system for reconciling existing taxonomic schemes with our rapidly expanding knowledge of Fusarium phylogeny. Additional phylogenetic research, likely based on much larger, genome-level data sets, will eventually be employed to reconstruct a more detailed evolutionary history of Fusarium and allow us to further assess its monophyly $(16,28)$. And most importantly, our rapidly expanding knowledge of Fusarium diversity must be communicated effectively to the user community - this will require a well-coordinated community effort and support mechanisms for digitally cataloging and sharing relevant data and cultures.

Despite these challenges, the future of Fusarium systematics should be viewed with tremendous optimism. A great degree of clarity has emerged in recent decades with regard to Fusarium species boundaries, subgeneric groups, and generic limits. A deluge of genomic data, which is on the way, will enable us to reevaluate Fusarium phylogeny and examine mechanisms underlying their evolution at the genome scale. Improved bioinformatic tools (31), in combination with the global connectivity enabled by the Internet, will provide researchers with rapid access to the information whenever and wherever they need it.

The concept of Fusarium has evolved to represent a very large and diverse set of taxa over the last century. While this size and diversity can present challenges, and arguments have abounded about species concepts in the genus, none of the previous major taxonomic treatments of Fusarium elected to break it up in a significant way. Along with the generic concept, an equally large and diverse community of researchers has evolved, leading to a long list of seminal discoveries in both practical and basic science that have had major impacts in plant pathology, medical mycology and fungal biology. Overall, we argue that the size and diversity of this genus is one of its most positive attributes, not a flaw in need of correction. As Booth said (4), "Taxonomists... must always be aware of the service element to other scientists. Taxonomy is a basic science fundamental to many branches of research.... and if we cannot give an indication of the true genealogical relationships that exist between the species we are failing in our profession." As did Gräfenhan et al. (16) and Schroers et al. (37), we offer this circumscription of Fusarium in that very spirit. However, the service element does not end with genealogical relationships. Once that criterion is satisfied, we must do everything we can to facilitate effective communication and research, and the simplest rule for doing that is not to make unnecessary changes.

\section{ACKNOWLEDGMENTS}

We thank P. Cantino for his helpful comments on the PhyloCode statement. We thank all of our colleagues for their helpful input and discussions on this important issue. The mention of firm names or trade products does not imply that they are endorsed or recommended by the U.S. Department of Agriculture (USDA) over other firms or similar products not mentioned. The USDA is an equal opportunity provider and employer. Manuscript no. 13-006-J from the Kansas Agricultural Experiment Station, Manhattan.

\section{LITERATURE CITED}

1. Aoki, T., O’Donnell, K., Homma, Y., and Lattanzi, A. R. 2003. Suddendeath syndrome of soybean is caused by two morphologically and phylogenetically distinct species within the Fusarium solani species complex-F. virguliforme in North America and F. tucumaniae in South America. Mycologia 95:660-684. 
2. Bilai, V. I. 1955. Fusarii. Izd. Akad. Nauk. Ukrain. SSR, Kiev.

3. Booth, C. 1971. The Genus Fusarium. Commonwealth Mycological Institute, Surrey, England.

4. Booth, C. 1978. Do you believe in genera? Trans. Br. Mycol. Soc. 71:1-9.

5. Booth, C. 1981. Perfect states (Telemorphs) of Fusarium species. In: Fusarium: Diseases, Biology, and Taxonomy. P. E. Nelson, T. A. Tousson, and R. J. Cook, eds. Penn State University Press, University Park, PA.

6. Cantino, P. D., and de Queiroz, K. 2010. PhyloCode: International Code of Phylogenetic Nomenclature, version 4c. edited by C. O. P. Nomenclature. http://www.ohio.edu/phylocode/PhyloCode4c.pdf

7. Chang, D. C., Grant, G. B., O’Donnell, K., Wannemuehler, K. A., NobleWang, J., Rao, C. Y., Jacobson, L. M., Crowell, C. S., Sneed, R. S., Lewis, F. M., Schaffzin, J. K., Kainer, M. A., Genese, C. A., Alfonso, E. C., Jones, D. B., Srinivasan, A., Fridkin, S. K., and Park, B. J. 2006. Multistate outbreak of Fusarium keratitis associated with use of a contact lens solution. JAMA 296:953-963.

8. Coleman, J. J., Rounsley, S. D., Rodriguez-Carres, M., Kuo, A., Wasmann, C. C., Grimwood, J., Schmutz, J., Taga, M., White, G. J., Zhou, S., Schwartz, D. C., Freitag, M., Ma, L. J., Danchin, E. G., Henrissat, B., Coutinho, P. M., Nelson, D. R., Straney, D., Napoli, C. A., Barker, B. M., Gribskov, M., Rep, M., Kroken, S., Molnar, I., Rensing, C., Kennell, J. C., Zamora, J., Farman, M. L., Selker, E. U., Salamov, A., Shapiro, H., Pangilinan, J., Lindquist, E., Lamers, C., Grigoriev, I. V., Geiser, D. M., Covert, S. F., Temporini, E., and VanEtten, H. D. 2009. The genome of Nectria haematococca: Contribution of supernumerary chromosomes to gene expansion. PLoS Genet. 5:e1000618.

9. Covert, S. F., Aoki, T., O’Donnell, K., Starkey, D., Holliday, A., Geiser, D. M., Cheung, F., Town, C., Strom, A., Juba, J., Scandiani, M., and Yang, X. B. 2007. Sexual reproduction in the soybean sudden death syndrome pathogen Fusarium tucumaniae. Fungal Genet. Biol. 44:799-807.

10. Crous, P. W., Gams, W., Stalpers, J. A., Robert, V., and Stegehuis, G. 2004. MycoBank: An online initiative to launch mycology into the 21st century. Stud. Mycol. 50:19-22.

11. Cuomo, C. A., Gueldener, U., Xu, J. R., Trail, F., Turgeon, B. G., Di Pietro, A., Walton, J. D., Ma, L. J., Baker, S. E., Rep, M., Adam, G., Antoniw, J., Baldwin, T., Calvo, S., Chang, Y. L., DeCaprio, D., Gale, L. R., Gnerre, S., Goswami, R. S., Hammond-Kosack, K., Harris, L. J., Hilburn, K., Kennell, J. C., Kroken, S., Magnuson, J. K., Mannhaupt, G., Mauceli, E., Mewes, H. W., Mitterbauer, R., Muehlbauer, G., Munsterkotter, M., Nelson, D., O’Donnell, K., Ouellet, T., Qi, W. H., Quesneville, H., Roncero, M. I. G., Seong, K. Y., Tetko, I. V., Urban, M., Waalwijk, C., Ward, T. J., Yao, J. Q., Birren, B. W., and Kistler, H. C. 2007. The Fusarium graminearum genome reveals a link between localized polymorphism and pathogen specialization. Science 317:14001402.

12. Dean, R., van Kan, J. A. L., Pretorius, Z. A., Hammond-Kosack, K. E., Di Pietro, A., Spanu, P. D., Rudd, J. J., Dickman, M., Kahmann, R., Ellis, J., and Foster, G. D. 2012. The top 10 fungal pathogens in molecular plant pathology. Mol. Plant Pathol. 13:414-430.

13. Gardiner, D. M., McDonald, M. C., Covarelli, L., Solomon, P. S., Rusu, A. G., Marshall, M., Kazan, K., Chakraborty, S., McDonald, B. A., and Manners, J. M. 2012. Comparative genomics reveals horizontally acquired novel virulence genes in fungi infecting cereal hosts. PLoS Pathogens 8:e1002952. doi:10.1371/journal.ppat.1002952

14. Gerlach, W., and Nirenberg, H. I. 1982. The Genus Fusarium-A Pictorial Atlas. Vol. 209, Mitt. Biol. Bundesanst. Land-Forstwirtsch. Paul Parey, Berlin-Dahlem.

15. Gordon, W. L. 1952. The occurrence of Fusarium species in Canada. II. Prevalence and taxonomy of Fusarium species in cereal seed. Can. J. Bot. 30:209-251.

16. Gräfenhan, T., Schroers, H.-J., Nirenberg, H. I., and Seifert, K. A. 2011. An overview of the taxonomy, phylogeny and typification of nectriaceous fungi in Cosmospora, Acremonium, Fusarium, Stilbella and Volutella. Stud. Mycol. 68:79-113.

17. Guadet, J., Julien, J., Lafay, J. F., and Brygoo, Y. 1989. Phylogeny of some Fusarium species, as determined by large-subunit ribosomal-RNA sequence comparison. Mol. Biol. Evol. 6:227-242.

18. Hawksworth, D. L. 2011. A new dawn for the naming of fungi: Impacts of decisions made in Melbourne in July 2011 on the future publication and regulation of fungal names. IMA Fungus 2:155-162.

19. Hirsch, J. E. 2005. An index to quantify an individual's scientific research output. Proc. Nat. Acad. Sci. USA 102:16569-16572.

20. Joffe, A. Z. 1974. A modern system of Fusarium taxonomy. Mycopathol. Mycol. Appl. 53:201-228.

21. Leslie, J. F., and Summerell, B. A. 2006. The Fusarium Laboratory Manual. Blackwell Publishing, Ames, IA.

22. Link, H. F. 1809. Observationes in ordines plantarum naturales. Dissertatio I. Magazin der Gesellschaft Naturforschenden Freunde Berlin 3.

23. Ma, L. J., van der Does, H. C., Borkovich, K. A., Coleman, J. J., Daboussi, M. J., Di Pietro, A., Dufresne, M., Freitag, M., Grabherr, M.,
Henrissat, B., Houterman, P. M., Kang, S., Shim, W. B., Woloshuk, C., Xie, X., Xu, J. R., Antoniw, J., Baker, S. E., Bluhm, B. H., Breakspear, A., Brown, D. W., Butchko, R. A., Chapman, S., Coulson, R., Coutinho, P. M., Danchin, E. G., Diener, A., Gale, L. R., Gardiner, D. M., Goff, S., Hammond-Kosack, K. E., Hilburn, K., Hua-Van, A., Jonkers, W., Kazan, K., Kodira, C. D., Koehrsen, M., Kumar, L., Lee, Y. H., Li, L., Manners, J. M., Miranda-Saavedra, D., Mukherjee, M., Park, G., Park, J., Park, S. Y., Proctor, R. H., Regev, A., Ruiz-Roldan, M. C., Sain, D., Sakthikumar, S., Sykes, S., Schwartz, D. C., Turgeon, B. G., Wapinski, I., Yoder, O., Young, S., Zeng, Q., Zhou, S., Galagan, J., Cuomo, C. A., Kistler, H. C., and Rep, M. 2010. Comparative genomics reveals mobile pathogenicity chromosomes in Fusarium. Nature 464:367-73.

24. Matuo, T. 1972. Taxonomic studies of phytopathogenic fusaria in Japan. Rev. Plant Prot. Res. 5:34-45.

25. Nalim, F. A., Samuels, G. J., Wijesundera, R. L., and Geiser, D. M. 2011. New species from the Fusarium solani species complex derived from perithecia and soil in the Old World tropics. Mycologia 103:1302-1330.

26. Nelson, P. E., Toussoun, T. A., and Marasas, W. F. O. 1983. Fusarium Species: An Illustrated Manual for Identification. The Pennsylvania State University Press, University Park, PA.

27. O'Donnell, K. 2000. Molecular phylogeny of the Nectria haematococcaFusarium solani species complex. Mycologia 92:919-938.

28. O’Donnell, K., Rooney, A. P., Proctor, R. H., Brown, D. W., McCormick, S. P., Ward, T. J., Frandsen, R. J. N., Lysøe, E., Rehner, S. A., Aoki, T., Robert, V. A. R. G., Crous, P. W., Kang, S., and Geiser, D. M. RPB1 and $R P B 2$ phylogeny supports an early Cretaceous origin and a strongly supported clade comprising all agriculturally and medically important fusaria. Fungal Genet. Biol. doi: 10.1016/j.fgb.2012.12.004

29. O'Donnell, K., Sutton, D. A., Fothergill, A., McCarthy, D., Rinaldi, M. G., Brandt, M. E., Zhang, N., and Geiser, D. M. 2008. Molecular phylogenetic diversity, multilocus haplotype nomenclature, and in vitro antifungal resistance within the Fusarium solani species complex. J. Clin. Microbiol. 46:2477-2490.

30. O’Donnell, K., Sutton, D. A., Rinaldi, M. G., Sarver, B. A. J., Balajee, S. A., Schroers, H. -J., Summerbell, R. C., Robert, V. A. R. G., Crous, P. W., Zhang, N., Aoki, T., Jung, K., Park, J., Lee, Y.-H., Kang, S., Park, B., and Geiser, D. M. 2010. An Internet-accessible DNA sequence database for identifying fusaria from human and animal infections. J. Clin. Microbiol. 48:3708-3718

31. Park, B., Park, J., Cheong, K.-C., Choi, J., Jung, K., Kim, D., Lee, Y.-H., Ward, T. J., O’Donnell, K., Geiser, D. M., and Kang, S. 2011. Cyber infrastructure for Fusarium: Three integrated platforms supporting strain identification, phylogenetics, comparative genomics and knowledge sharing. Nucleic Acids Res. 39(Suppl. 1):D640-D646.

32. Raillo, A. I. 1950. Fungi of the Genus Fusarium. Government Publishers of Agricultural Literature, Moscow.

33. Rossman, A. Y., and Palm-Hernandez, M. E. 2008. Systematics of plant pathogenic fungi: Why it matters. Plant Dis. 92:1376-1386.

34. Rossman, A. Y., Samuels, G. J., Rogerson, C. T., and Lowen, R. 1999. Genera of Bionectriaceae, Hypocreaceae and Nectriaceae (Hypocreales, Ascomycetes). Stud. Mycol. 42:1-248.

35. Samuels, G. J., and Hallett, I. C. 1983. Microdochium stoveri and Monographella stoveri, new combinations for Fusarium stoveri and Micronectriella stoveri. Trans. Br. Mycol. Soc. 81:473-483.

36. Scauflaire, J., Gourgue, M., and Munaut, F. 2011. Fusarium temperatum sp. nov. from maize: An emergent species closely related to Fusarium subglutinans. Mycologia 103:586-597.

37. Schroers, H.-J., Gräfenhan, T., Nirenberg, H. I., and Seifert, K. A. 2011. A revision of Cyanonectria and Geejayessia gen. nov., and related species with Fusarium-like anamorphs. Stud. Mycol. 68:115-138.

38. Schroers, H. J., O’Donnell, K., Lamprecht, S. C., Kammeyer, P. L., Johnson, S., Sutton, D. A., Rinaldi, M. G., Geiser, D. M., and Summerbell, R. C. 2009. Taxonomy and phylogeny of the Fusarium dimerum species group. Mycologia 101:44-70.

39. Seifert, K. A. 2001. Fusarium and anamorph generic concepts. In: Fusarium: Paul E. Nelson Memorial Symposium. B. A. Summerell, J. F. Leslie, D. Backhouse, W. L. Bryden, and L. W. Burgess, eds. American Phytopathological Society, St. Paul, MN.

40. Snyder, W. C., and Hansen, H. N. 1940. The species concept in Fusarium. Am. J. Bot. 27:64-67.

41. Snyder, W. C., and Hansen, H. N. 1941. The species concept in Fusarium with reference to section Martiella. Am. J. Bot. 28:738-742

42. Snyder, W. C., and Hansen, H. N. 1945. The species concept in Fusarium with reference to Discolor and other sections. Am. J. Bot. 32:657-666.

43. Van Etten, H. D. 1978. Identification of additional habitats of Nectria haematococca mating population VI. Phytopathology 68:1552-1556.

44. Wingfield, M. J., De Beer, W., Slippers, B., Wingfield, B. D., Groenewald, J. Z., Lombard, L., and Crous, P. W. 2011. One fungus, one name promotes progressive plant pathology. Mol. Plant Pathol. DOI: 10.1111/J.1364-3703.2011.00768.X 
45. Wingfield, B. D., Steenkamp, E. T., Santana, Q. C., Coetzee, M. P. A., Bam, S., Barnes, I., Beukes, C. W., Chan, W. Y., de Vos, L., Fourie, G., Friend, M., Gordon, T. R., Herron, D. A., Holt, C., Korf, I., Kvas, M., Martin, S. H., Mlonyeni, X. O., Naidoo, K., Phasha, M. M., Postma, A., Reva, O., Roos, H., Simpson, M. Slinski, S., Slippers, B., Sutherland, R., van der Merwe, N. A., van der Nest, M. A., Venter, S. N., Wilken, P. M., Yandell, M., Zipfel, R., and Wingfield, M. J. 2012. First fungal genome sequence from Africa: A preliminary analysis. S. Afr. J. Sci. 108:537.

46. Wollenweber, H. W., and Reinking, O. A. 1935. Die Fusarien, ihre Beschreibung, Schadwirkung, und Bekämpfung. Paul Parey, Berlin. 